\title{
Integrated Geophysical Study of the Lower Indus Platform Basin Area of Pakistan
}

\author{
Nasir Khan", Ahmed Amara Konaté, Peimin Zhu \\ Institute of Geophysics and Geomatics, China University of Geosciences (Wuhan), Wuhan, China \\ Email: " nasirkhan.geophysicst@hotmail.com
}

Received August 28, 2013; revised September 29, 2013; accepted October 27, 2013

Copyright (C) 2013 Nasir Khan et al. This is an open access article distributed under the Creative Commons Attribution License, which permits unrestricted use, distribution, and reproduction in any medium, provided the original work is properly cited.

\begin{abstract}
Integrating various data sets to provide one optimal subsurface image is a major goal of geophysicst. In this paper, there is a synergetic approach used to delineate the tectonic-structural framework with analyzing the hydrocarbon reservoir in the Lower Indus Platform basin of Pakistan. The reflected seismic profiles and potential field map constitute the data base of this study. Our study in the line of the previous research is resulted from important oil and gas discoveries contained in the Early Cretaceous and Upper Jurassic formations of the Lower Indus Platform basin area. The result shows trapping mechanism in the Lower Indus Platform basin involves of the fault blocks and stratigraphic traps are present in the area. The more refined images are interpreted to provide greater insight into detailed integrated geophysical study of area.
\end{abstract}

Keywords: Integrated Geophysical Study; Exploration Geophysics; Lower Indus Platform Basin

\section{Introduction}

The Lower Indus Platform basin is one of the Pakistan's tectonostratigraphic provinces, which is geographically located in the Sindh province of Pakistan between longitudes $23^{\circ}$ and $23^{\circ} 31 \mathrm{~N}$ and latitudes from $66^{\circ} \mathrm{E}$ respectively. The location of the Lower Indus Platform is shown in Figure 1 [1]. Pakistan is divided tectonically into two major divisions, the Western Makran basin having an oceanic crust (Arabian Plate) and Eastern Indus basin with a continental crust (Indian Plate) with Murray Ridge/ Owen Fracture as the dividing line between these two [2]. The Eastern Indus Basin is subdivided into three geological Provinces [3]. The Lower Indus Platform basin belongs to the Indus platform and fore deep zone of tectonics framework. The vast sedimentary basins cover about $80 \%$ of the total country's area with widespread oil and gas seepages. Despite the long history of oil and gas exploration and an attractive petroleum policy, the sedimentary basins still contain sizeable areas, classified as frontiers, which cover more than $60 \%$ of the total prospective area including the Pishin Basin, the Maluan-I Charan Basin, Fold and Thrust Belt parts of the Platform of the Indus Basin and the entire Offshore [4,5]. Presently, about 421 exploratory wells have been dug all

\footnotetext{
${ }^{*}$ Corresponding author.
}

across Pakistan. In the Southern Indus Basin 55 exploratory wells were drilled during the period 1955-1984, but 27 of these wells were based on the results of multifold seismic surveys [6]. In the past hundreds of years of petroleum research, compared to an average of one hundred wells in other similar basins, Pakistan remained one of the least explored basins of which the well density is less than five per $10,000 \mathrm{sq} \cdot \mathrm{Kms}$. The country desperately needs to exploit new oil and gas potentials across the new frontiers to increases self-reliance. For sustainable exploration, more efforts should be directed towards these frontier areas which after exploration may prove to be of greatest potential [7]. This paper briefly highlights the hydrocarbon potential and deep crustal structure of Lower Indus Platform basin deduced from the study of seismic and gravity data. The identification of existing petroleum systems and assessment of undiscovered oil and gas potential analogies with other basins suggest that there is significant potential for many hydrocarbon discoveries present in this basin [7]. But it requires a commitment from both the oil companies and the government to achieve success. New plays concepts need to be utilized with new technology along with advanced geological and geophysical studies that highlight the potential of these areas. This study analyzes this area in order to describe the potentialities of this basin which has emerged 


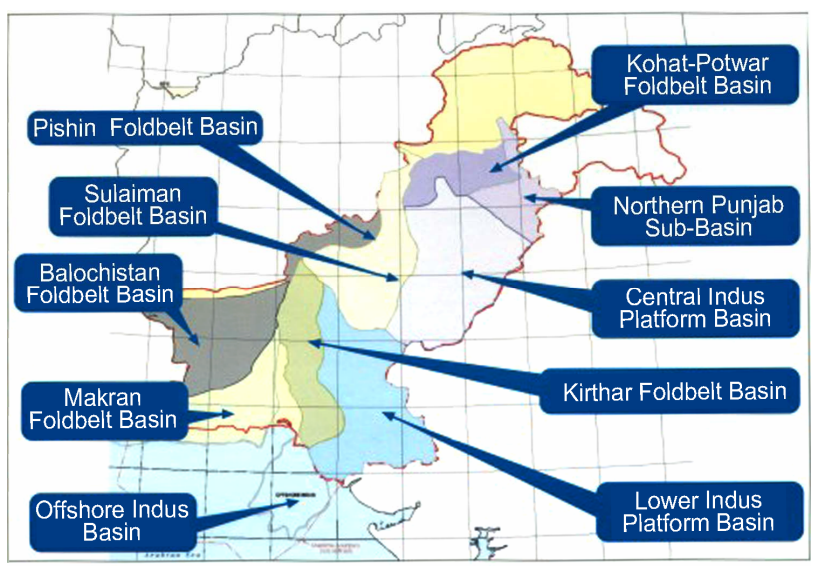

Figure 1. Representing the location of the area (GSP Pakistan, 1982).

in the past few years as a major petroleum province due to many major oil and gas discoveries along with many other discoveries in Pakistan. A variety of structural styles and depositional regimes are associated with this area.

\section{Geological Background and Stratigraphy of the Area}

The Lower Indus Platform Basin is bounded to the North by the Central Indus Basin, to the Northwest by the Sulaimanfoldbelt Basin and the Kirthar Fold Belt Basin in the Southwest. The area lies in the tectonic zone of the "Indus plate form and fore deep" which comprises of many structural zones. The structural features which are present in the area are tilted fault blocks, thrust-faulted anticlines, and anticlines. The anticlines and thrusted anticlines occur in the foreland portions of the Indus basin as a result of compression related to collision of the Indian and Eurasian plates [8]. This tectonic province is underlain by infra-Cambrian to recent clastics and carbonates. It retained a passive margin until the Late Cretaceous, then became part of the complex suture between the Indian Plate and the Afghan Block. The tectonic activity affecting the structures and sedimentology of the Lower Indus Plate form basin including rifting of the Indian Plate from Gondwanaland (Jurassic or Early Cretaceous), which probably created NE-SW to N-S rift systems, and isostatic uplift or ridge-push at the margins [9]. At Cretaceous-Tertiary boundary during Cretaceous age, the thermal doming, strike-slip faulting, and hotspot activity occurred due to the separation of the Indian and Madagascan plates. This resulted in uplift, erosion, extrusion of the Deccan flood basalts and probably the NNWstriking normal faults [9]. There are Paleocene-Eocene emplacements of the Bela Ophiolites which caused gentle folding, the passive margin conditions of Eocene caused structural quiescence and carbonate deposition [10].
The Himalayan Oligocene to present-day collision caused sinistral transpression in the west of the Lower Indus Basin, due to which with fold-thrust structures overprinted by sinistral flower structures [9]. The stratigraphic sequence of the Middle and Lower Indus Basin with full details is also as shown in the Table $\mathbf{1}$ [11]. The stratigraphic succession changes from east to west. The Precambrian basement is westward. The important unconformities occur at the base of the Permian and the Tertiary. In the eastern part of the basin, the Tertiary has direct contact with the Jurassic sequence [12]. The Indus Lower Indus Platform basin reflects sedimentation associated with rifting.

Table 1. Representing the stratigraphic details of the area (Kadri, 1995).

\begin{tabular}{|c|c|c|c|}
\hline \multirow{2}{*}{ Era } & \multirow{2}{*}{ Period } & \multirow{2}{*}{ Epoch } & Lower Platform Basin \\
\hline & & & Formations \\
\hline \multirow{8}{*}{ Cenozoic } & \multirow{3}{*}{ Quaternary } & Pliestocene & Lei conglomerate \\
\hline & & Pliocene & Siwaliks group \\
\hline & & Miocene & Gaj formation \\
\hline & \multirow{6}{*}{ Tertiary } & Oligocene & Nari formation \\
\hline & & Focene & Kirthar formation \\
\hline & & Loverit & Lakhi formation \\
\hline & & & Lakhara fm \\
\hline & & Paleocene & Bara fm \\
\hline \multirow{14}{*}{ Mesozoic } & & & Khadro fm \\
\hline & \multirow{6}{*}{ Cretacious } & \multirow{4}{*}{ Late } & Pab sandstone \\
\hline & & & Fortmunro member \\
\hline & & & Moghal kot fm \\
\hline & & & Farh fm \\
\hline & & \multirow[t]{2}{*}{ Early } & Goru fm \\
\hline & & & Sember fm \\
\hline & \multirow{5}{*}{ Jurassic } & \multicolumn{2}{|l|}{ Late } \\
\hline & & Middle & Mazar dirk \\
\hline & & (2) & Chiltan fm \\
\hline & & Early & Shirinab fm \\
\hline & & Late & \\
\hline & \multirow[t]{2}{*}{ Triassic } & Middle & Wulgai formation \\
\hline & & Early & \\
\hline \multirow{6}{*}{ Paleozoic } & \multirow[t]{2}{*}{ Permian } & Late & \\
\hline & & Early & \\
\hline & \multicolumn{2}{|c|}{ Carboniferrous to ordovician } & \\
\hline & & Late & Not exposed/drilled \\
\hline & \multirow[t]{2}{*}{ Cambrian } & Middle & \\
\hline & & Early & \\
\hline Precambris & & & \\
\hline
\end{tabular}




\section{Data and Research Methodology}

Data for this research was acquired as part of a project to reassess the oil and gas exploration potential through a regional potential field data survey of the area and a seismic data survey in the Lower Indus Plate form basin area of Pakistan. We have applied the potential field data to understanding the basement character as interpretation of the basement geology which is important for developing and evaluating oil and gas plays for the deeper parts of the basin as well as understanding the regional tectonic history. Integrating the potential field data has helped in refining the interpretation of the prospective part of the basin. The research methodology is carried out by using Interpretation of the potential field data and seismic data of the Lower Indus Platform basin area of Pakistan.

\section{Interpretation of the Potential Field Data}

The potential field data in the study area consists of regional bouger gravity, residual gravity, total magnetic intensity, second derivatives regional maps and a series of prospect-oriented gravity and magnetic profiles or maps. The regional maps represented in Figure 2 the gradient of bouger anomaly gravity, isostatic anomalies and magnetic depth and basement elements. Through the available data it was concluded that the Lower Indus Platform basin represents anomaly appears that have reflect actual density intensity data shown as distribution of rocks. It can be concluded that there is steep positive gravity gradient towards the southwest above thick sedimentary strata and the depression areas attributed to a rise in the mantle while the depth model indicates that the overall gravity effect is typical. The crustal thickness is more than $20 \mathrm{~km}$ thick towards the Northeast and is reduced to $7 \mathrm{Km}$ on the mantle rise. The available intensity magnetic data shows magnetic field variations from over -100 is the Southwest to -50 gamma over much of the North Eastern area [13], which reflect seismic structure in south and southeastern areas. The crust is transitional. The presence of thick sedimentary rocks of various lithologies which commonly form source-reservoir seal trilogies and optimum geothermal gradients analogies shows that there are a number of structural traps whose age range from Cretaceous to Miocene and provide evidence of hydrocarbon. Due to thinning of the crust, the younger sediments may have attained maturity. Source rock material of organic clays is deposited in an anaerobic environment, and peaty formation forms residual coal deposits and source material for petroleum and natural

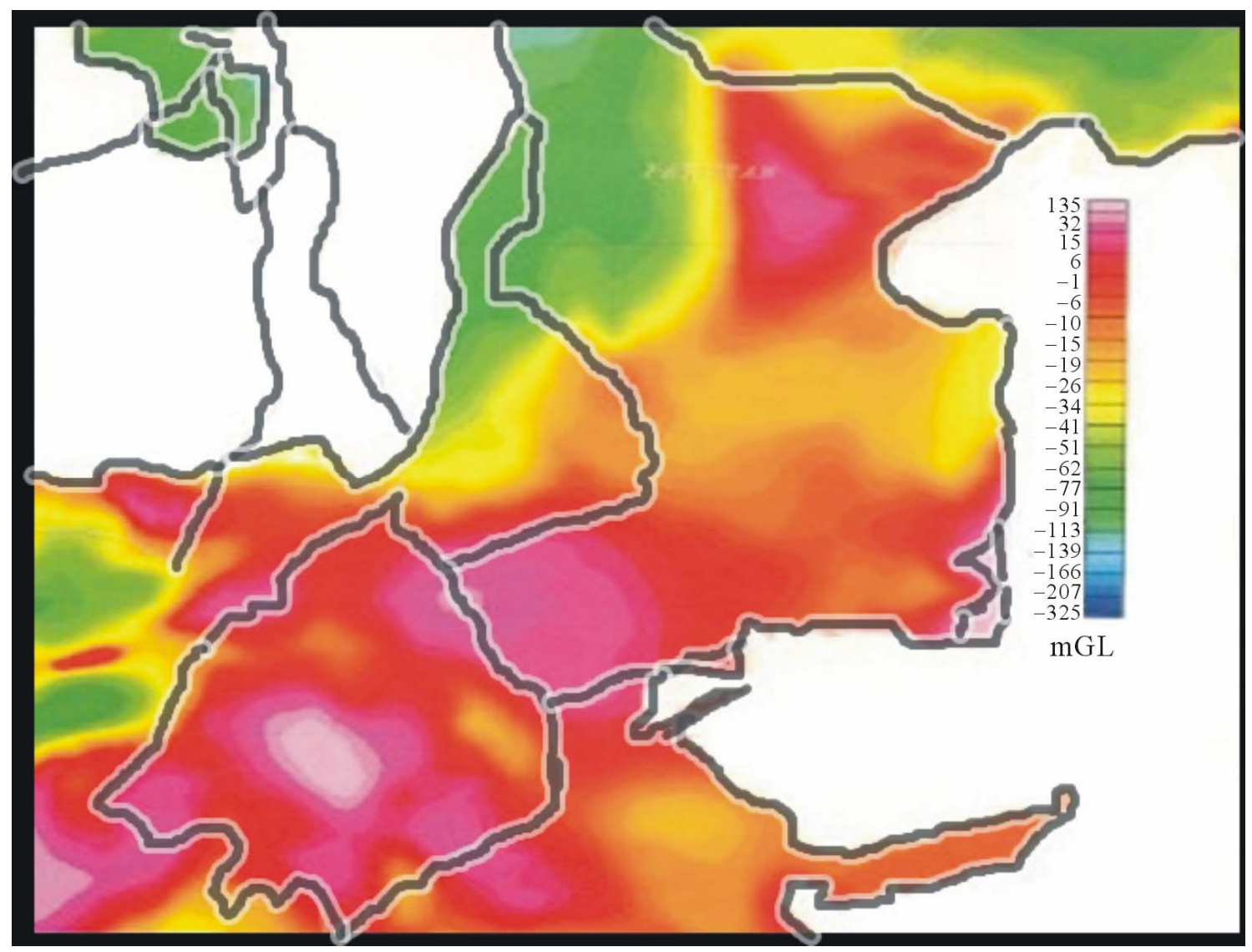

Figure 2. Representing gradient of bouger anomaly gravity, isostatic anomalies; magnetic depth and basement element map. 
gas. The reservoir rocks, which are deposited are porous and permeable rocks and are carbonates and sandstones. Some carbonates reservoirs owe their porosity and permeability to digenetic and tectonic modification of the original sediments and are interceded with potential cap rocks. For the crustal modeling, the following parameters were used: the average density distribution of rocks in the Lower Indus Platform basin, which is about $2.8 \mathrm{~g} / \mathrm{cm}$ and the crustal velocity, taken as $6.4 \mathrm{k} / \mathrm{m}$ [14]. The mean mantle velocity is about $8.1 \mathrm{k} / \mathrm{m}$ as by [15]. The Isostatic behavior of the area has been studied by calculating Isostatic Mohofor normal crust of $30 \mathrm{Km}$. [16]. The interpreting anomalies which indicate the presence of basic rocks and various rocks types having structural features such as faults and fold have been traced. Due to lacking of integration with corresponding seismic and well information for this study, qualitative and quantitative interpretation of the gravity and magnetic data was performed in conjunction with regional reflection profiles and exploratory drill hole information. The results of this synergetic approach show a provisional correlation of the potential field with reflection data exposing the tectonic-structural interpretation.

\section{Seismic Data and Integrated Interpretation}

Our analysis shows that most of the misinterpretations suggested above can be avoided by incorporating seismic information, particularly for isolating the real sources of local magnetic and gravity anomalies. The acquired seismic data base consists of regional and detail seismic of various vintages. Migration was also applied to the acquired data and then processed. These lines constitute the main grids from which the refined structure and paleotectonic evolution of the area were deciphered. The time-to-depth conversion of available seismic data using Layer Cake method after marking good reflectors assigns ages on the basis of well and long range correlation and velocity analysis which can be comparable to $[13,17]$. The [18] interval velocities were computed for each interval (layer) in the sedimentary wedge above the basement using Gardner relationship [19], and bulk densities were computed as given in Table 2 . The sedimentary structure was interpreted from the seismic reflection data, the density contrasts used for each seismic sequence have been taken against the crust of mean density $2.8 \mathrm{gm} / \mathrm{cm}^{3}$. There is a complex structural deformation of the Jurassic starta and many different fault systems. Faults are represented on the seismic sections (Figures 3 and 4) as a discontinuous reflection along a preferred orientation of reflectors. The seismic sections that belong to the Lower Indus platform basin are represented in Figures 3 and $\mathbf{4}$. The interpretation of seismic lines demonstrated the presence of two main seismic events, viz. "syn-rift" and
Table 2. Average densities for different lithologies.

\begin{tabular}{cccc}
\hline Layers & Lithologies & $\begin{array}{c}\text { Density } \\
\left(\mathrm{gm} / \mathrm{cm}^{3}\right)\end{array}$ & $\begin{array}{c}\text { Density } \\
\text { Contrast }\left(\mathrm{gm} / \mathrm{cm}^{3}\right)\end{array}$ \\
\hline Layer-1 & Miocene & 2.26 & -0.52 \\
Layers-2 & Oligocene & 2.24 & -0.39 \\
Layer-3 & Eocene & 2.65 & -0.23 \\
Layer-4 & Paleocene & 2.70 & -0.19 \\
Layer-5 & Cretaceous & 2.76 & -0.18 \\
Layer-6 & Jurassic & 2.81 & -0.15 \\
Layer-7 & Triassic & 2.85 & -0.13 \\
Crust & Basement & 2.90 & +0.00 \\
Mantle & Mantle & 3.25 & +0.45 \\
\hline
\end{tabular}

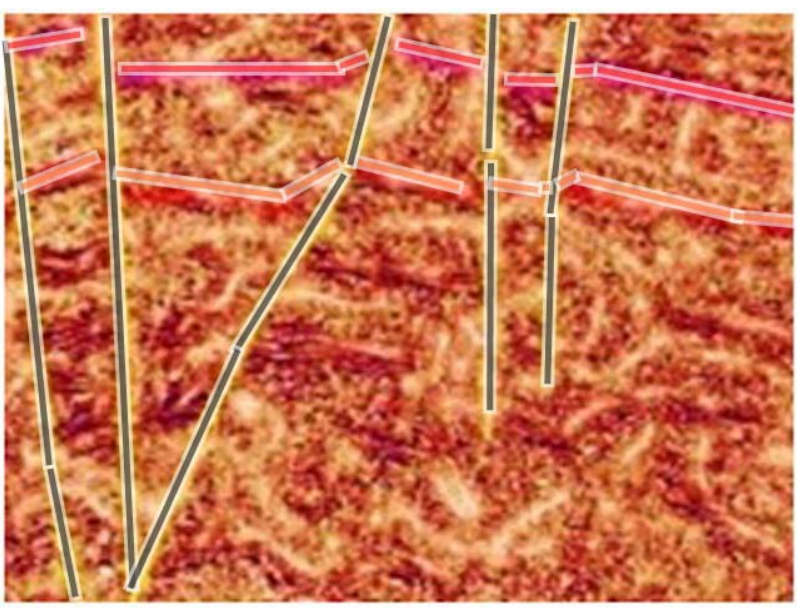

Figure 3. Representing the seismic data from Lower Indus Platform basin area.

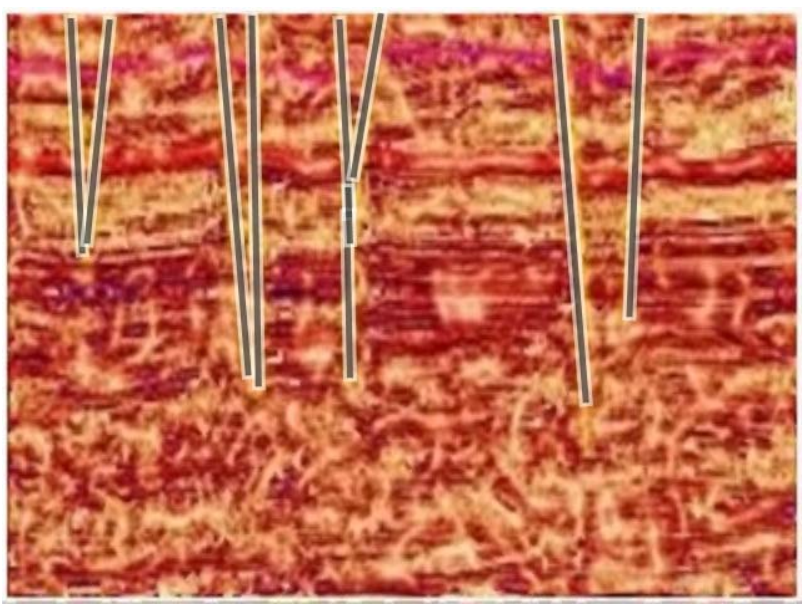

Figure 4. Representing the seismic data from Lower Indus Platform basin area.

post-rift. The Late Miocene regression in the area caused large scale channeling followed by the growth fault related structures, evident on the seismic section [20]. The subsurface structures are related to normal faults in the 
east and listric normal faults and diapiric structures in the west [21]. The divergent pattern of seismic reflections from the strata within the basin suggests that the processes of continental rifting and deposition were contemporaneous. The younger sequence seems to have been affected by minor reactivation of an older fault. The fault bounding the basin is regarded as normal and listric in form indicating extension and accompanied with rotation of the basement block. The cap rocks are present for all potential reservoirs such as intra-formational shale for Lower Cretaceous reservoirs. The reservoirs are Cretaceous to Eocene clastics and carbonates, proven due to the presence of rich hydrocarbon discoveries in the Lower Indus platform basin. The Cretaceous rocks are potential source rocks for hydrocarbon in the area. The reservoirs which are older are present towards the east and northeast. The mature source rocks which are relatively younger are present towards the west. The structural evolution of a Lower Indus Basin is therefore controlled mainly by the amount of initial crustal thinning that occurs during the rifting phase as well as subsequent tectonic subsidence. The tectonic subsidence is a result of the cooling of thinned lithosphere (thermal contraction). The process of thinning produces a thermal anomaly due to passive upwelling of hot asthenosphere. The regional seismic lines clearly show very thick sediments in the area which delineate the structural configuration. The quality of existing seismic has allowed for conclusive interpretation. However, combined information from seismic, potential field, and well data enables identification of potential fields, while well data enables the identification of major structural and tectonic elements, estimation of their size and geometry, and understanding of their spatial and temporal relationship.

\section{Conclusions}

We have used the integrated geophysical approach in this study of the Lower Indus Platform basin which has proven to be efficient using reflection seismic profiles and potential field maps.

We have concluded that the trapping mechanis midentified from our interpretation indicates that Lower Indus Platform basin reservoir rocks have tremendous reserves of hydrocarbons and the tectonics modification of the basin has formed variety of trap structures. We have also concluded that the reservoir rocks which are deposited are porous and permeable rocks and are present in carbonates and sandstones, and the sources rocks are allshaley in nature. The reflected seismic profiles and potential field maps can be integrated into the practice for hydrocarbon exploration. We hope that our research study will be very useful for the exploration and production activities to explore and to enhance the energy deficiency and to fulfill needs requirements for the economy of the country and also can be used for anyone who interested in research geophysics. We suggest that there is need to do the research on the basis of integrating well logging data with seismic data by using neural network technology.

\section{REFERENCES}

[1] A. H. Kazmi and R. A. Rana, "Tectonics Map of Pakistan," Geological Survey, Pakistan, 1982.

[2] H. A. Raza and R. Ahmed, "Hydrocarbon Potential of Pakistan," Journal of Canada Pakistan Cooperation, Vol. 4, No. 1, 1990, pp. 9-27.

[3] S. M. Shuaib, "Geology and Hydrocarbon Potential of Offshore Indus Basin,” AAPG Bulletin, Vol. 66, No. 7, 1982, pp. 940-946.

[4] H. A. Raza, R. Ahmed, S. Alam and S. M. Ali, "Petroleum Zones of Pakistan," Pakistan Journal of Hydrocarbon Research, Vol. 1, No. 2, 1989, pp. 1-19.

[5] H. A. Raza, "Exploration Strategy for Frontier Regions of Pakistan," 1st Annual Technical Convention of PAPG, Islamabad, 26-27 September 1997.

[6] V. Quadri and S. M. Shuaib, "Hydrocarbon Prospects of Southern Indus Basin, Pakistan," AAPG Bulletin, Vol. 70, No. 6, 1986, pp. 730-747.

[7] E. G. Bowles, "Under Explored Basins of Pakistan, an Oil Company's Perspective," 1st Annual Technical Convention of PAPG, Islamabad, 26-27 September 1997.

[8] A. H. Kazmi and M. Q. Jan, "Geology and Tectonics of Pakistan," Graphic Publishers, Karachi, 1997.

[9] M. Z. Farshori, "The Geology of Sindh," University of Sindh, Jamshoro, 1972.

[10] R. B. Smith and R. L. Bruhn, "Interpolate Extensional Tectonics of the Eastern Basin Range-Inferences on Structural Style from Seismic Reflection Data, RegionalTectonics and Thermal-Mechanical Models of BrittleDuctile Deformation," Journal of Geophysical Research, Vol. 89, No. B7, 1984, pp. 5733-5762.

[11] I. B. Kadri, "Petroleum Geology of Pakistan," Pakistan Petroleum Limited, Ferozsons (pvt) Limited, 1995.

[12] M. W. A. Iqbal and S. M. I. Shah, "A Guide to the Stratigraphy of Pakistan," Geological Survey of Pakistan, Quetta, 1980.

[13] A. Naveed, "Speculative Models for the Crust and Upper Mantle Beneath the Indus Offshore Basin," A Preliminary Study Based on Limited Deep Seismic Reflection and Potential Field Anomaly Data, OGDC Petro Canada Indus Offshore Report, 1987.

[14] J. E. Nafe and C. L. Drake, "Physical Properties of Marine Sediments," In: M. N. Hill, Ed., The Sea, 1963, pp. 794-813.

[15] I. N. Christensen, "Elasticity of Ultrabasic Rocks," Journal of Geophysical Research, Vol. 71, No. 24, 1966, pp. 5921-5930.

[16] B. R. Naini and M. Talwani, "Structural Framework and the Evolutionary History of the Continental Margin of 
Western India,” AAPG Memoir, 1983.

[17] I. S. Rafat, "A Critical Review of Seismic P-Wave Velocities and Demonstration of their Utilization in Seismic Data Interpretation," M.Phi1. Thesis, Quaid-i-Azam University, Islamabad, 1996.

[18] C. H. Dix, "Seismic Velocities from Surface Measurements," Geophysics, Vol. 20, No. 1, 1955, pp. 68-86. http://dx.doi.org/10.1190/1.1438126

[19] G. H. F. Gardner, L. W. Gardner and A. R. Gregory, "Formation Velocity and Density-The Diagnostic Basis for Structural Traps," Geophysics, Vol. 39, No. 6, 1974, pp. 770-780. http://dx.doi.org/10.1190/1.1440465

[20] S. U. Siddiqui, "Hydrocarbon Potential, Offshore Pakistan," 1st Annual Technical Convention of P.A.P.G., Islamabad, 26-27 September 1997.

[21] R. Ahmed, S. M. Ali and J. Ahmed, "Review of Petroleum Occurrence and Prospects of Pakistan with Special Reference to Adjoining Basins of India, Afghanistan and Iran," Pakistan Journal of Hydrocarbon Research, Vol. 6, No. 1-2, 1994, pp. 7-18. 